\title{
Mathematical Connections Of Students Based On Learning Style Using Blended Learning
}

\author{
Hardi $^{1 *}$, H Suyitno ${ }^{2}$, Kartono $^{2}$, and N K Dwidayati ${ }^{2}$ \\ ${ }_{1,2}$ Postgraduate Mathematics Education Program, Semarang State University, Indonesia \\ "Corresponding author: hardi.fit@ iain-surakarta.ac.id
}

Article History: Received: 11 January 2021; Accepted: 27 February 2021; Published online: 5 April 2021

\begin{abstract}
In the process of learning mathematics many students can not make connections in mathematics, thus causing the ability of students in mathematical connections to be low. This problem is characterized by insufficient methods and approaches to improve math achievement in students. The purpose of this study was to find out the difference in mathematical connection ability of students of Madrasah Ibtidaiyah Teacher Education (PGMI) IAIN Surakarta reviewed from the learning style by using blended learning. Based on the results of the study showed that there are differences in the ability of mathematical connections of students who use blended learning and expository. Blended learning tends to have higher value than expository learning. Indicators of connection with other science disciplines scored highest for both control and experiment classes. As for the learning style in the highest comprehension experiment class for mathematical connections, students have the type of audio learning style while the lowest for visual learning style type.
\end{abstract}

Keywords: mathematical connections, learning styles, blended learning

\section{Introduction}

Permendiknas no. 22 year 2006 mentions that m atematika is one of the subjects learned by studentsstarting from elementary school, secondary school even to higher education. This is intended to equip students with logical, analytical, systematic, critical and creativethinking and the ability to worktogether, and one of the objectives of mathematics learning so that students understand mathematical concepts, explain the interrelationship of concepts and apply concepts or algorithms flexibly, accurately, efficiently, and appropriately in problem solving (DEPDIKNAS, 2006). In other words, the purpose of mathematics learning is to try to connect concepts with each other, with other subjects and their connection to the environment. These connections are more familiar with mathematical connections or connections.

Basically every student has a mathematical connection ability, it's just that the level of ability varies (Puteri and Riwayati, 2017) for that mathematical connection ability must be used in learning so that students can solve problems in the future by connecting problems with mathematical concepts in other fields of science, so what has been learned in school is useful inlife. A person's ability to associate intertopic in mathematics, associate mathematics with other sciences, and with life is called mathematical connection ability (Siagian, 2016; Defitriani, 2018; Hendriana et al, 2018; Princess et al, 2020).

Mathematical connections are part of a network of knowledge that is interconnected with other knowledge consisting of critical concepts of understanding and developing relationships between mathematical ideas, concepts, and procedures, it can be said that mathematical connections are the ability to associate students' mathematical knowledge with other math and real life skills thus opening up opportunities for students to develop math skills. So that a person who understands the relationship between mathematical concepts well, then he not only memorizes or remembers the concept in the short term but mastery of the concept is more durable and he is able to apply the concept to other situations (Nurafni and Pujiastuti, 2019).

Mathematical connections have several indicators, namely: 1) Know and use the relationship between mathematical ideas. In this case, connections can help students to take advantage of the concepts they have learned in a new context to be learned so that students can re-remember the previous conceptslearned, 2) Understand the interrelationship of mathematical ideas and shape ideas with each other so as to generate a complete connection. At this stage studentsare able to see the same mathematical structure in different settings, so that there is an increased understanding of the relationship between one concept and another concept. 3) Get to know and apply mathematics in real life. The external contexts of mathematics at this stage relate to the relationship of mathematics with daily life(NCTM, 2000).

Sumarmo (Romli, 2016) states that mathematical connections are activities that include: (1) finding relationships between various representations of concepts and procedures, (2) understanding the relationship between mathematical topics, (3) using mathematics in other fields of study or daily life, (4) finding connections or other procedures in equivalent representations, and (5) using connections between mathematical topics and between topics with other topics. Through this mathematical connection students learn to make estimates and develop their thoughts using insights within a particular context to test a contingency in another context (Romli, 2016). So that when students can connect the material they learned from previous subjects or with other subjects, then the results of mathematics learning become more meaningful (Lintoet al,2012). 
There are many factors that affect students' learning outcomes so that they become meaningful, one of which is by using strategies, approaches or models in their learning. The learning process that generally happens is through face-to-face, but sometimes this is considered terlalu ancient so that by applying e-learning to the learning process will not be outdated and provide results that are in accordance with expectations and more effective (Abdullah,2018). However, the learning process that only utilizes technology alone cannot be fully successful. This is because eachstudent'slearning style varies. Students who have visual and audio learning styles may succeed in following the learning with the application of e-learning, but for students who have kinesthetic learning style may have a small chance of succeeding in the learning process (Wardani et al, 2018).

One of the learning that is considered effectiveto facilitate learning style and able to improve mathematical connection ability is by blended learning model. This learning model combines face-to-face learning with elearning (Husamah, 2014; Wardani et al, 2018). Blended learning enables students to learn independently by utilizing materials available online so that they can discuss with teachers not only during classroom learning, but also by adding enrichment materials through internet facilities (Husamah, 2014) so that it is expected that the learning contexts are more varied that allow for increased ability of mathematical connections of students. So that the purpose of the research carried out is toknow the picture of differences inmathematicalconnection ability of PGMI IAIN Surakarta students reviewed from the learning style by using blended learning.

\section{METHOD PENELITIAN}

\section{Research Design}

Research method in the research is metode combination with concurrent triangulation design. This research method combines qualitative and quantitative research methods by mixing the two methods in a balanced manner with a percentage of 50\% quantitative method and 50\% qualitative method (Sugiono, 2013). This method is a popular method among other combination methods karena both methods are used in thesame time, then in terms of time will be more efficient (Creswell, 2013; Sugiono, 2016).

\section{Population and sample}

Population is the whole subject of research that is the main subject of discussion. Popuasi in this study was a Teacher Education Student of Madrasah Ibtidaiyah Faculty of Tarbiyah Sciences and IAIN Surakarta Teacher Training which consisted of 3 classes, while the sample was 2 classes. One class is used as an experimental class using blended learning while the other class is a control class with an expository learning model.

\section{Data collection}

The variables tied to this study are mathematical connections and learning styles. So the following indicators of mathematical connection capability in table 1.

\section{Table 1. Mathematical Connection Capability Indicator}

\begin{tabular}{|r|r|l|}
\hline \multicolumn{1}{|c|}{$\begin{array}{c}\text { Mathematical Connection } \\
\text { Capability Form }\end{array}$} & \multicolumn{1}{|c|}{ Indicator } \\
\hline 1 & $\begin{array}{l}\text { Get to know and use relationships between } \\
\text { math topics. }\end{array}$ & $\begin{array}{l}\text { Students are able to write down the } \\
\text { mathematical ideas underlying the answers then } \\
\text { connect with new ideas or other topics }\end{array}$ \\
\hline 2 & $\begin{array}{l}\text { Understanding the interconnectedness of } \\
\text { mathematical ideas and shaping ideas with } \\
\text { each other so as to produce a connection with } \\
\text { other sciences }\end{array}$ & $\begin{array}{l}\text { Students are able to form a linkage of } \\
\text { mathematical ideas so as to produce a } \\
\text { comprehensive association with other } \\
\text { disciplines }\end{array}$ \\
\hline 3 & $\begin{array}{l}\text { Get to know and apply mathematics in } \\
\text { everyday life (real). }\end{array}$ & $\begin{array}{l}\text { Students are able to connect the events that } \\
\text { exist in daily life (real) into the mathematical } \\
\text { model and find a solution. }\end{array}$ \\
\hline
\end{tabular}

While another variable is the learning style. It can be said that the learning style is a characteristic of cognitive, affective and psychomotor behavior, as an indicator of a relatively stable action for pemlearningtofeel interconnected and react to the learning environment. There are three types of learning style in this research,namely:visual, auditorial, and kinesthetic (Deporter\&Hernacki, 2000).

Here is a collection of data to answer the research objectives described in table 2 below. 
Table 2. Research Data collection

\begin{tabular}{|c|c|c|c|}
\hline${ }_{0}^{\mathrm{N}}$ & Problem Formulation & $\begin{array}{l}\text { Data Collection } \\
\text { Techniques }\end{array}$ & $\begin{array}{l}\text { Data } \\
\text { Source }\end{array}$ \\
\hline 1 & $\begin{array}{l}\text { Ability of Mathematics Connection in PGMI } \\
\text { IAIN Surakarta Students control class and } \\
\text { experimental class }\end{array}$ & Test & Students \\
\hline 2 & $\begin{array}{l}\text { Is there a difference in the ability of } \\
\text { mathematical connections based on learning with } \\
\text { Blended Learning in students of Teacher } \\
\text { Education Madrasah Ibtidaiyah IAIN Surakarta } \\
\text { reviewed from visual learning style }\end{array}$ & $\begin{array}{c}\text { Documents, } \\
\text { Questionnaires } \\
\text { andTests, interviews }\end{array}$ & Students \\
\hline 3 & $\begin{array}{l}\text { There are differences in the ability of } \\
\text { mathematical connections based on learning with } \\
\text { Blended Learning in students of Teacher } \\
\text { Education Madrasah Ibtidaiyah IAIN Surakarta } \\
\text { reviewed from auditory learning style. }\end{array}$ & $\begin{array}{c}\text { Documents, } \\
\text { Questionnaires } \\
\text { andTests, interviews }\end{array}$ & Students \\
\hline 4 & $\begin{array}{l}\text { Is there a difference in the ability of } \\
\text { mathematical connections based on learning with } \\
\text { Blended Learning in students of Teacher } \\
\text { Education Madrasah Ibtidaiyah IAIN Surakarta } \\
\text { reviewed from kinesthetic learning style }\end{array}$ & $\begin{array}{c}\text { Documents, } \\
\text { Questionnaires } \\
\text { andTests, interviews }\end{array}$ & Students \\
\hline
\end{tabular}

\section{Data Analysis}

The step of research step combination of concurrent triangulation model can depart from the formulation of similar qualitative or quantitative problems. Researchers use qualitative methods, then researchers must strengthen themselves into human instruments in order to collect, and analyze qualitative data, and when becoming quantitative researchers, researchers conduct theoretical studies to be formulated hypotheses and research instruments. Research instruments are used to collect quantitative data. Qualitative data that has been collected is analyzed qualitatively, and quantitative data is analyzed with statistics. The two data groups of qualitative and quantitative analysis results are then analyzed again with metaanalysis to be grouped, distinguished, and searched none data with the other data, so that whether the two data strengthen each other, weaken or conflict. To answer the purpose of the problem disclosed, the following table is presented on the steps in the research described in the diagram of the research steps.

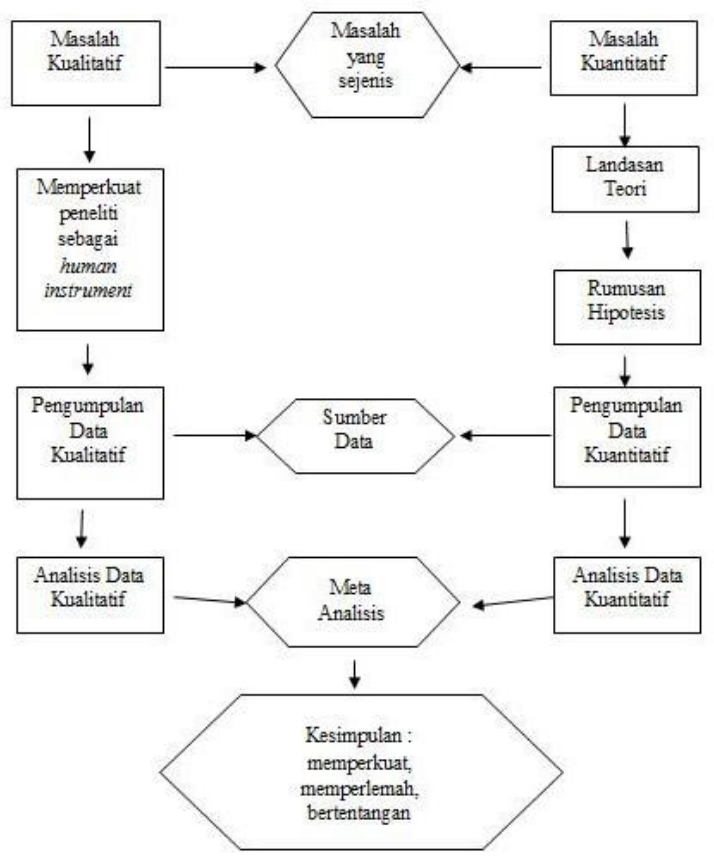

Figure 3.1

Steps of concurrent triangulation method 


\section{RESEARCH RESULTS}

In this study, the students' mathematical connection ability with blended learning was reviewed from the learning style. Student math connection ability data is obtained from tests for control classes and experimental classes. In addition to seeing the ability of mathematical connections, but also based on his learning style. The data obtained is described to find out the development of mathematics connection ability of PGMI IAIN Surakarta students in mathematics courses. The picture of students' mathematical connection ability results can be seen in figure 2 below:

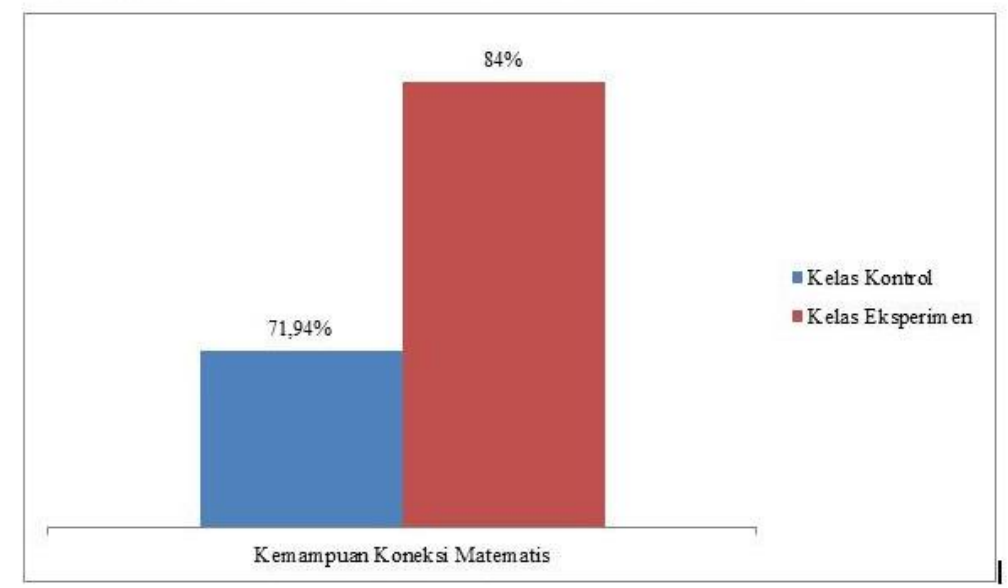

Figure 2: Mathematical Connection Capability

Figure 2 shows the overall results of mathematical connection capabilities. From the tests conducted in can be different results of mathematical connection ability using blended learning. For experimental classes by $84 \%$ while for control classes of $71,94 \%$. there is a difference of $12.6 \%$. this indicates that blended learning is effective enough to see mathematical connection capabilities. The effectiveness of blended learning that can improve mathematical ability, because it is possible that this learning habits students to be able to interact with each other, discuss exchange opinions or ideas on certain problems (Astuti\& Novita, 2019) because in blended learning combines information and communication technology so as to optimize learning (Elliot, 2002; Syarif, 2012).

Here we can also see the differences in mathematical connection capability results of each indicator for control classes and experiment classes in graph 3.

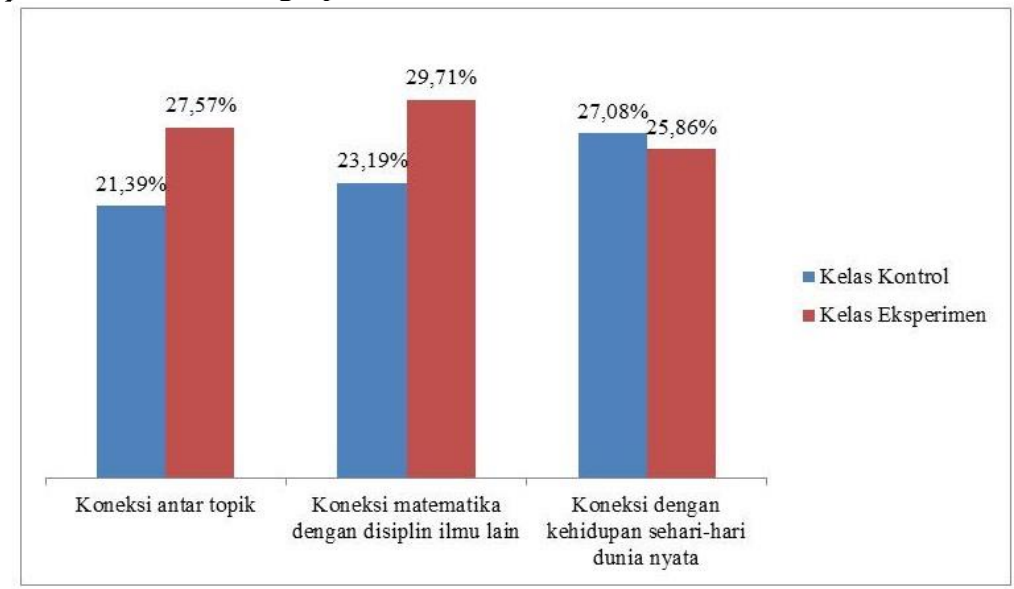

Figure 3 : Results of Mathematical Connection Capability of Each Indicator

For indicator 1 about mathematical connections there is a difference of 6.8 results between the control class and the experiment class, for indicator number 2 is the mathematical connection with other disciplines the difference is 6.52, while for indicator number 3 about the connection with daily life in the real world the difference is 1.22 . The biggest difference for control classes and experimental classes is in indicator number 2 , which indicates that blended learning is most effective at knowing the ability to mathematically connect with other disciplines. This is because the ability of connection will be more effective if there is a similar meaning that the speaker wants toconvey with meaning understood by the listener(Yulianto and Supritihaningsih 2019). With blended learning, it is possible to be more motivated (Hinkelman\&Gruba, 2012; Altay \&Altay, 2019) explores various effectivenesses, helping to sharpen students' way of thinking that can eventually improve mathematical connections with other disciplines so that they can understand more meaningfully (Johar\& Ahmad, 
2014; Kastner, 2020). As for indicator number 3 tentang connection with sahari-day life shows that the control class is superior to see such capabilities.

The results of mathematical connection ability reviewed from learning styles also vary for control classes and experimental classes, as described in figure 4.

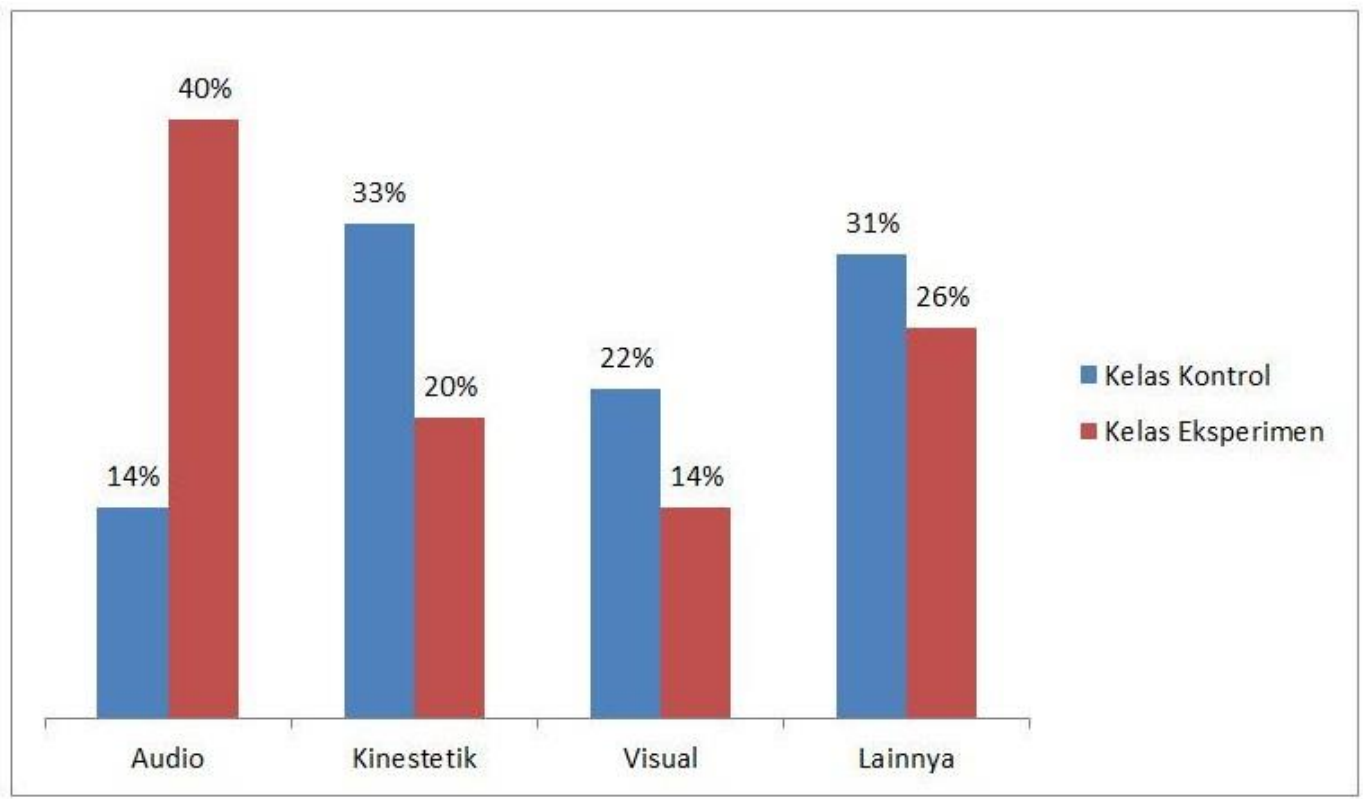

Figure 4: Mathematical Connection Capabilities for Learning Style Types

Figure 4 shows that the type of audio learning style in the experimental class has the best value for mathematical connection capability with blended learning, while for the best mathematical connection capability control class there is a kinetic learning style type of 33. For the lowest score on mathematical connections the experimental class is in the visual learning style type, while for the control class there is an audio learning style type. But in this study there can also be other results for the type of learning style described in the word "other". other results can be based on interviews. The results showed that for control classes in other types of style learning had a high score of 33 for mathematical connections, while for experimental classes of 26.

The results that have been described are in line with research from Wardani et al (2018) which states that for visual and audio learning style types are likely to be more effective when following learning based on e learning or in other words with blended learning. Based on this, it is expected that lecturers plan the learning process in accordance with the type of student's learning style (Tomlinson, 2001; Zeybek, \&Şentürk, 2020)

\section{CONCLUSIONS AND SUGGESTIONS}

Based on the results of research and discussion wecan conclude some points,dianataranya that: 1) there are differences in the ability of mathematical connections of students in the control class and experimental classes that use blended learning; 2) blended learning isvery effective to improve the ability of mathematical connections for students with the type of visual and audio learning style namunthereare still some students who have not been able to determine what type of learning style they have.

Based on the conclusion of the research, it can be put forward some suggestions as follows: 1). blended learning can be used as an alternative for lecturers to improve the ability ofmathematicalconnectionss students; 2). in the teaching and learning process should pay attention to the differences in student learning styles, so that it can be pursued to handle problems or difficulties of students in solving mathproblems; 3). advanced research for learning using blended learning for other mathematical abilities.

\section{REFFERENCES}

1. Abdullah, W. 2018. Model Blended Learning DalamMeningkatkanEfektifitasPembelajaran. FIKROTUNA: Jurnal Pendidikan dan Manajemen Islam Volume 7, Nomor 1, Juli 2018; p-ISSN 2442- 2401; e-ISSN 2477-5622.

2. Altay, I.F., Ayse Altay. 2019. A Review of Studies on Blended Learning in EFL Environment.International Journal of Curriculum and Instruction 11(1) (2019) 125-140. 
3. Astuti, D.A., Novita, D. 2019. Blended Learning Terhadap Kemampuan Komunikasi Matematis. Prosiding Sendika:Vol 5, No 1. 2019.

4. Creswell, D.A. 2015. PenelitianKualitatif dan Desain Riset. Yogyakarta: Pustaka Belajar.

5. Defitriani, E. 2018. MengembangkanKemampuanKoneksiMatematisSiswaMelaluiPendekatan Differentiated Instruction. Anargya: Jurnalllmiah Pendidikan Matematika, 1(2), 72-76.

6. Depdiknas. 2006. PermendiknasNomor 22 Tahun 2006 TentangStandar Isi SekolahMenengah Atas. Jakarta: Depdiknas.

7. DePorter, Bobby \&Hernacki, Mike. 2000. Quantum Learning: MembiasakanBelajarNyaman dan Menyenangkan. Bandung:Kaifa.

8. Elliot, M. 2002. Blended Learning:The Magic Is In The Mix. In A. Rossett (ed). The ASTD elearning Handbook (pp.58-63). New York: McGraw-Hill.

9. Hendriana, Rohaeti, and Sumarmo, Hard Skill dan Soft Skill MatematikSiswa. Bandung: PT RefikaAditama, 2018.

10. Hinkelman, D., Gruba, P. 2012. Power within blended language learning programs in Japan. Language Learning \& Technology, 16(3), 46-64.

11. Husamah. 2014. PembelajaranBauran, Blended Learning. Jakarta: Prestasi Pustaka Publisher.

12. Kastner, J.A. 2020. Blended learning: beyond the thread quality of blended learning andinstructors experiences. Journal of Educators Online, 2020.

13. Linto., RendyaLogina., Sri Elnita., YusmetRizal. 2012. Kemampuankoneksimatematis dan metodepembelajaran Quantum Teaching dengan peta pikiran. Jurnalpendidikanmatematika, Vol.1, No.1, 83-87.

14. NCTM. 2000. Principle and Standars for School Mathematic. Virginia. NCTM.

15. Nurafni, A.,HeniPujiastuti. 2019.AnalisisKemampuanKoneksiMatematisditinjaudari Self Confidence Siswa: StudiKasus Di SMKN 4 Pandeglang. ANARGYA: Jurnalllmiah Pendidikan Matematika Vol.2 No.1 April 2019 p-ISSN: $2615-4196$ e-ISSN: $2615-4072$ http://jurnal.umk.ac.id/index.php/anargya.

16. Putri, E.RBudiyono, Diari I. 2020. POGIL model on mathematical connection ability viewed from self-regulated learning. International Journal of Evaluation and Research in Education (IJERE) Vol. 9, No. 2, June 2020, pp. 394 400.ISSN: 2252-8822, DOI:10.11591/ijere.v9i2.20321.

17. Puteri, J.W.,SelviRiwayati. 2017. KemampuanKoneksiMatematisSiswa Pada Model PembelajaranConneted Mathematics Project(CMP). FIBONACCI: Jurnal Pendidikan Matematika dan Matematika Volume 3 No. 2 BulanDesemberTahun2017. ISSN: 2460 - 7797 e-ISSN: 2614-8234.

18. Romli, M. 2016. ProfilKoneksiMatematisSiswa Perempuan SmaDenganKemampuanMatematika Tinggi DalamMenyelesaikanMasalahMatematika. MUST: Journal of Mathematics Education, Science and Technology Vol. 1, No. 2, Desember 2016. Hal 144 - 163.

19. Siagian, M.D. 2016. KemampuanKoneksiMatematikDalamPembelajaranMatematika. MES (Journal of Mathematics Education and Science)Vol. 2, No. 1, Oktober 2016. ISSN: 2528-4363.

20. Syarif, I. 2012. Pengaruh Model Blended Learning TerhadapMotivasi Dan PrestasiBelajarSiswa SMK. Jurnal Pendidikan Vokasi, 2(2), 234-249.

21. Tomlinson, C. A. (2001). How to differentiate instruction in mixed-ability classrooms. Alexandria, VA: Association for Supervision and Curriculum DevelopmentPublications.

22. Sugiono. 2016. MetodePenelitianKombinasi (Mixed Methods). Bandung: Alfabeta.

23. Wardani, D.N., et al. (2018). Daya Tarik Pembelajaran di Era 21 dengan Blended Learning. Jurnal Kajian Teknologi Pendidikan, 1(1), 13-18.

24. Yulianto, H.,Siti Supritihaningsih. 2019. KemampuanKomunikasiMatematis pada PembelajaranTreffingerBerdasarkan Self Efficacy.Prosiding Seminar Nasional Pascasarjana UNNES 2019.ISSN: 2686-6404.

25. Zeybek, G., \&Şentürk, C. 2020. Analysis of preservice teachers' learning stylesaccording to Vermunt learning style model. International Online Journal of Education and Teaching (IOJET), 7(2). 669-682.https://iojet.org/index.php/IOJET/article/view/766 